\title{
PENGARUH FAKTOR INTERNAL DAN EKTERNAL TERHADAP RETURN SAHAM PERUSAHAAN MAKANAN DAN MINUMAN DI BURSA EFEK INDONESIA PERIODE 2008- 2011
}

\author{
Erric Wijaya ${ }^{2}$ \\ Tinjung Desy Nursanti ${ }^{3}$
}

\begin{abstract}
This study aims to look at the impact of internal and external factors to the stock return of food and beverage companies listed in the Indonesia Stock Exchange 2008 to 2011 period. The method used is the regression equation analysis of panel data using a common effect type. The results show that the internal factors such current ratio, debt to equity ratio and return on assets showed a positive and significant influence on the company's stock return of food and beverage industry in the BEI. While external factors namely SBI interest rate and economic growth showed a different result, where the $S B I$ interest rate has a negative and significant relationship to the company's stock return, while economic growth has no significant negative relationship to the stock returns.
\end{abstract}

Keywords: stock return, current ratio, debt to equity ratio, return on asset, economic growth

\section{PENDAHULUAN}

\section{Latar Belakang Masalah}

Pasar modal merupakan sarana yang efektif bagi perusahaan dalam menghimpun dana untuk mengembangkan perusahaan menjadi lebih baik di masa yang akan datang. Pasar modal adalah pertemuan antara pihak yang memiliki kelebihan dana (lenders) dengan pihak yang membutuhkan dana (borrowers) dengan cara memperjualbelikan sekuritas. Secara umum perusahaan dapat memperoleh dana dengan cara meminjam ke bank, akan tetapi dalam hal ini bank memiliki keterbatasan untuk menyalurkan kredit, karena bank memiliki keterkaitan dengan otoritas moneter yang setiap saat melakukan monitoring terhadap jumlah uang beredar dan untuk menjaga stabilitas moneter sehingga kerap kali perusahaan mengalami kesulitan untuk mendapatkan dana cepat dari bank (Usman, Riphat, Ika, 1997). Oleh karena itu, pasar modal dapat menjadi alternatif bagi perusahaan dalam mendapatkan dana cepat dengan menjual sebagian atau bahkan kepemilikan asset perusahaan tersebut kepada investor atau pemilik dana.

Para investor atau pemilik dana dapat memilih perusahaan mana saja dana yang dimilikinya akan diinvestasikan dengan harapan memperoleh hasil yang baik di masa yang akan datang 
dengan didasarkan atas intuisi, ketelitian dan analisa yang cermat. Oleh karena itu, seorang investor perlu melakukan analisis terhadap faktor-faktor internal maupun faktor-faktor eksternal dalam melakukan penilaian investasi. Analisis terhadap faktor internal yang merupakan aspek fundamental menjadi sangat penting bagi investor dalam menilai kinerja perusahaan. Kinerja perusahaan dapat dilihat melalui laporan keuangan yaitu tercermin dalam perhitungan rasio keuangan yang antara lain dapat digunakan untuk mengukur risiko dan profitabilitas perusahaan. Perhitungan rasio keuangan dilakukan untuk mengetahui sejauh mana sekuritas yang diinvestasikan akan menghasilkan keuntungan di kemudian hari dengan melihat berbagai kemungkinan buruk yang terjadi. Adapun faktor-faktor eksternal yang dimaksud meliputi inflasi, suku bunga yang ditetapkan Bank Indonesia, pertumbuhan ekonomi, nilai tukar mata uang dan berbagai faktor ekonomi makro yang mempengaruhi perekonomian baik secara langsung maupun tidak langsung.

Beberapa penelitian sebelumnya sehubungan dengan pengaruh faktor internal dan eksternal terhadap return saham, antara lain dilakukan oleh Andyono (2009) bertujuan untuk mengetahui ada tidaknya pengaruh dari faktor fundamental perusahaan yang digambarkan dengan book-to-market ratio, kebijakan pendanaan perusahaan, dan ukuran perusahaan, serta kondisi makroekonomi yang digambarkan melalui inflasi, tingkat suku bunga SBI, dan pertumbuhan PDB sektor tambang terhadap imbal hasil saham perusahaan pertambangan pada periode 2004-2008 dengan rentang data tahunan. Hasil penelitiannya menunjukkan bahwa bookto-market ratio, ukuran perusahaan, tingkat inflasi, tingkat suku bunga SBI, dan pertumbuhan PDB sektor tambang memiliki pengaruh yang signifikan. Sedangkan kebijakan pendanaan perusahaan tidak memiliki pengaruh yang signifikan terhadap tingkat imbal hasil saham pertambangan. Penelitian ini dapat dijadikan acuan bagi investor dalam mengambil keputusankeputusan berinvestasi terutama pada saham-saham pertambangan. Penelitian lainnya dilakukan oleh Utami dan Rahayu (2009) memberikan hasil bahwa perubahan profitabilitas, suku bunga, inflasi dan nilai tukar mempunyai pengaruh secara signifikan terhadap perubahan harga saham badan usaha selama periode krisis ekonomi. Secara parsial hanya suku bunga dan nilai tukar mempunyai pengaruh secara signifikan terhadap harga saham selama periode krisis ekonomi tersebut. Sedangkan penelitian Subalno (2009) terhadap 17 perusahaan otomotif dan komponen yang terdaftar di BEI selama periode 2003-2007 memberikan hasil analisis regresi secara parsial bahwa return on asset, nilai tukar dan suku bunga SBI berpengaruh signifikan terhadap return saham, sedangkan current ratio, debt to equity ratio dan total asset turn over tidak berpengaruh secara signifikan terhadap return saham.

Dari hal-hal yang telah dipaparkan di atas, maka dilakukan penelitian ini untuk melihat sejauh mana faktor internal yaitu kinerja keuangan yang diindikasikan melalui rasio keuangan yang meliputi current ratio, debt to equity ratio, dan return on asset serta faktor eksternal yang meliputi pertumbuhan ekonomi dan tingkat suku bunga SBI dapat mempengaruhi return saham pada industri makanan dan minuman di BEI periode 2008-2011. Pemilihan perusahaan makanan dan minuman sebagai sampel, didasari alasan bahwa perusahaan makanan dan minuman tidak terlalu terpengaruh oleh faktor siklikal, tergolong dalam sektor industri barang konsumsi yang relatif lebih stabil dalam berbagai kondisi ekonomi sehingga dapat membagikan dividen secara rutin setiap tahun, bukan merupakan industri musiman sehingga konsumen akan terus membutuhkan produk yang dihasilkan industri ini untuk memenuhi kebutuhan sehari-hari, masih sedikitnya perusahaan-perusahaan makanan dan minuman yang mencari dana melalui pasar 
modal dan tidak sebanding dengan jumlah perusahaan makanan dan minuman yang ada di Indonesia.

\section{PERUMUSAN MASALAH}

Adapun perumusan masalah dalam penelitian ini adalah :

1. Apakah current ratio, debt to equity ratio, return on asset, tingkat bunga SBI dan pertumbuhan ekonomi secara partial berpengaruh signifikan terhadap return saham perusahaan makanan dan minuman di Bursa Efek Indonesia periode 2008-2011.

2. Apakah current ratio, debt to equity ratio, return on asset, suku bunga SBI dan pertumbuhan ekonomi secara simultan berpengaruh signifikan terhadap return saham perusahaan makanan dan minuman di Bursa Efek Indonesia periode 2008-2011?

\section{TUJUAN PENELITIAN}

1. Untuk mengetahui dan menganalisis pengaruh current ratio, debt to equity ratio, return on asset, tingkat bunga SBI, dan pertumbuhan ekonomi secara parsial terhadap return saham perusahaan makanan dan minuman di Bursa Efek Indonesia periode 2008-2011.

2. Untuk mengetahui dan menganalisis pengaruh current ratio, debt to equity ratio, return on asset, tingkat bunga SBI, dan pertumbuhan ekonomi secara simultan terhadap return saham perusahaan makanan dan minuman di Bursa Efek Indonesia periode 2008-2011.

\section{LANDASAN TEORI}

\section{Pasar Modal, Harga Pasar Saham dan Return Saham}

Pasar modal secara umum adalah suatu sistem keuangan yang terorganisasi, termasuk di dalamnya adalah bank-bank komersial dan semua lembaga perantara dibidang keuangan, serta keseluruhan surat-surat berharga yang beredar. Pada dasarnya pasar modal tidak berbeda dengan pasar lainnya. Pada pasar lain umumnya pembeli dapat memperoleh segala keterangan atau informasi dari penjual sedangkan di pasar modal, informasi diperoleh antara lain dengan membaca prospektus perusahaan.

Menurut Ang (1997) harga pasar merupakan harga yang paling mudah ditentukan karena harga pasar merupakan harga suatu saham pada pasar yang sedang berlangsung. Jika pasar bursa efek sudah tutup, maka harga pasar adalah harga penutupan (closing price). Jadi harga pasar inilah yang menyatakan naik turunnya suatu saham. Semakin tinggi harga saham berarti semakin tinggi pula kekayaan pemegang saham. Menurut Mankiw (2006) saham merupakan tanda penyertaan atau kepemilikan seseorang atau badan dalam suatu perusahaan. Saham dapat dibedakan antara saham biasa (common stock) dan saham preferen (preferred stock) dengan karakteristik yang melekat pada masing-masing tipe saham.

Adapun yang menjadi dasar keputusan investasi adalah tingkat return yang diharapkan, tingkat risiko serta hubungan antara return dan risiko. Return saham adalah sesuatu yang diharapkan akan diperoleh atau cash flow yang diantisipasi dari setiap investasi yang dilakukan (Jones, 2007). Return yang diharapkan investor dari investasi yang dilakukan merupakan kompensasi atas biaya kesempatan (opportunity cost) dan risiko penurunan daya beli akibat adanya pengaruh inflasi. Investasi yang dilakukan baik jangka pendek maupun jangka panjang 
mempunyai tujuan utama yaitu mendapatkan keuntungan yang disebut return yang terdiri dari current income dan capital gain. Current income merupakan keuntungan yang diperoleh melalui pembayaran yang bersifat periodik seperti pembayaran bunga deposito, bunga obligasi, dividend dan sebagainya. Sedangkan capital gain merupakan keuntungan yang diterima karena adanya selisih antara harga jual dengan harga beli saham dari suatu instrument, yang berarti bahwa saham tersebut harus diperdagangkan di pasar.

\section{Pengaruh Faktor Internal}

Menurut Jogiyanto (2003: 282) likuiditas yang diukur dengan current ratio yaitu aktiva lancar dibagi kewajiban lancar diprediksi mempunyai hubungan yang negatif dengan risiko karena diketahui semakin liquid perusahaan semakin kecil risikonya. Current ratio menunjukkan bahwa nilai kekayaan lancar sebesar sekian kalinya hutang jangka pendek.

Debt to equity ratio (DER) mencerminkan kemampuan perusahaan dalam memenuhi seluruh kewajibannya yang ditunjukkan oleh berapa bagian modal sendiri yang digunakan untuk membayar hutang. Kebijakan debt dapat dipengaruhi oleh karakteristik-karakteristik perusahaan yang akan mempengaruhi kurva permintaan dari debt yang ditawarkan kepada perusahaan atau permintaan perusahaan akan debt (Ang, 1997). Rasio ini menunjukkan besarnya hutang yang digunakan untuk membiayai aktiva yang digunakan oleh perusahaan dalam rangka menjalankan aktivitas operasionalnya.

Return On Asset (ROA) merupakan rasio profitabilitas yang digunakan untuk mengukur efektifitas perusahaan di dalam menghasilkan keuntungan dengan memanfaatkan aktiva yang dimilikinya. ROA yang semakin besar menunjukkan kinerja perusahaan yang semakin baik, karena tingkat pengembalian investasi meningkat. Meningkatnya ROA juga akan meningkatkan pendapatan dividen (terutama cash dividend).

\section{Pengaruh Faktor Eksternal}

Pertumbuhan ekonomi menggambarkan tingkat kemajuan ekonomi suatu Negara. Negara yang pertumbuhan ekonominya tinggi biasanya aktivitas perekonomiannya tinggi juga. Indikator pertumbuhan ekonomi adalah GDP yang merupakan nilai pasar output barang dan jasa yang diproduksi dinegara dalam periode tertentu. Untuk menentukan pertumbuhan ekonomi menggunakan pendekatan GDP harga konstan (GDP riil).

Di Indonesia perubahan tingkat suku bunga dipengaruhi oleh kebijakan moneter pemerintah lewat penentuan SBI. Pergerakan SBI dapat menentukan keputusan investor dalam berinvestasi. Bila pemerintah menetapkan kenaikan tingkat suku bunga melebihi dari expected return investor maka investor akan berpikir untuk menjual sahamnya dan berinvestasi pada deposito atau tabungan yang bebas resiko dan akan memberikan return lebih tinggi, dan sebaliknya apabila pemerintah menetapkan menurunkan suku bunga dibawah expected return, maka investor akan memilih membeli dan berinvestasi di saham daripada berinvestasi di deposito atau tabungan.

\section{KERANGKA PENELITIAN}

Berdasarkan tujuan penelitian untuk mengetahui dan menganalisis pengaruh dari current ratio, debt to equity ratio, return on asset, pertumbuhan ekonomi dan suku bunga SBI terhadap 
return saham perusahaan makanan dan minuman di Bursa Efek Indonesia, baik secara individual maupun secara simultan, secara skematis dapat ditunjukkan dalam kerangka pemikiran penelitian pada gambar berikut:

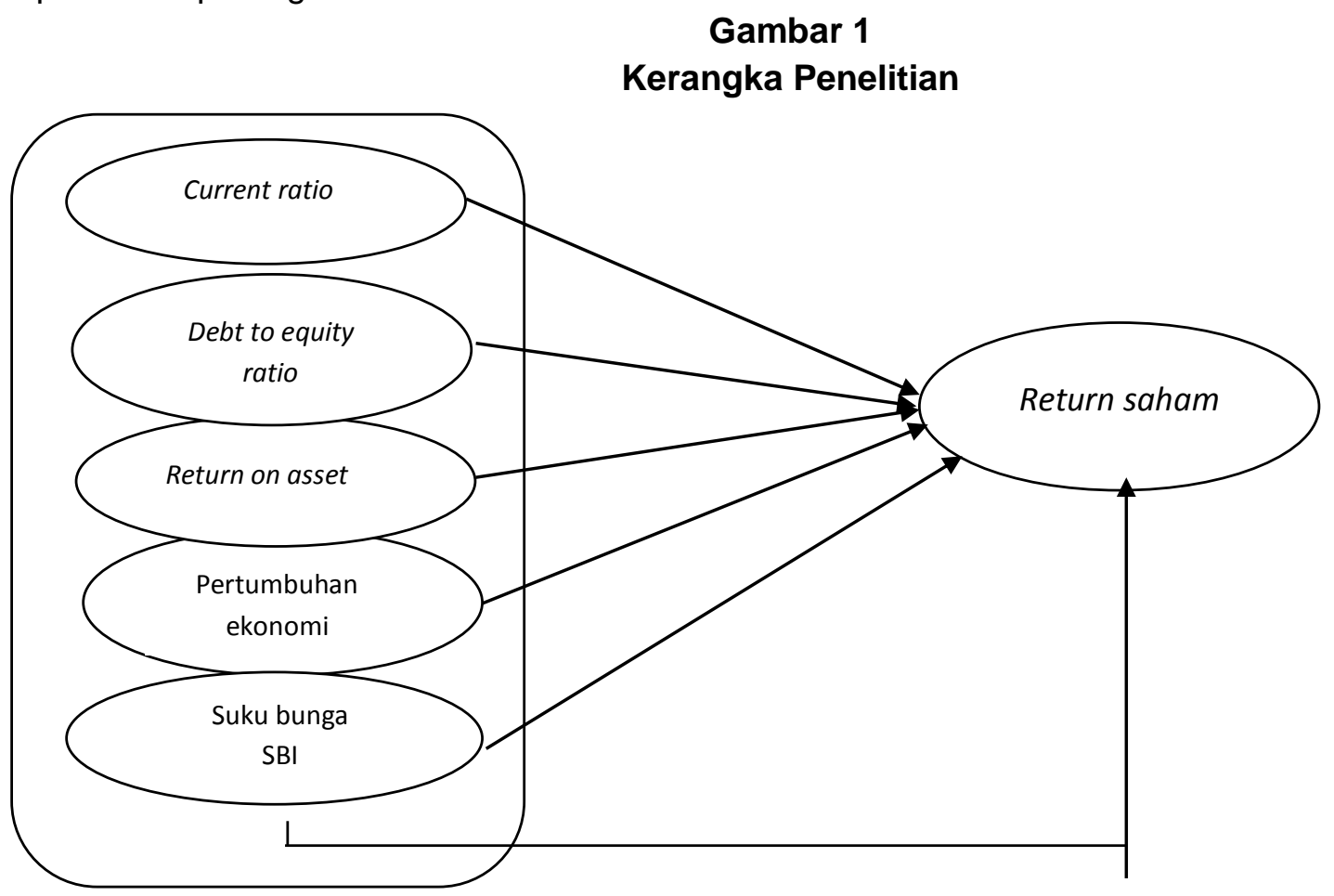

Sumber: Olahan penulis

\section{Hipotesis}

$\mathrm{H}_{01}$ Tidak terdapat pengaruh signifikan secara parsial current ratio terhadap return saham perusahaan makanan dan minuman di Bursa Efek Indonesia periode 2008-2011.

$\mathrm{H}_{\mathrm{A} 1}$ Terdapat pengaruh signifikan secara parsial current ratio terhadap return saham perusahaan makanan dan minuman di Bursa Efek Indonesia periode 2008-2011.

$\mathrm{H}_{02}$ Tidak terdapat pengaruh signifikan secara parsial debt to equity ratio terhadap return saham perusahaan makanan dan minuman di Bursa Efek Indonesia periode 2008-2011.

$\mathrm{H}_{\mathrm{A} 2}$ Terdapat pengaruh signifikan secara parsial debt to equity ratio terhadap return saham perusahaan makanan dan minuman di Bursa Efek Indonesia periode 2008-2011.

$\mathrm{H}_{03}$ Tidak terdapat pengaruh signifikan secara parsial return on asset terhadap return saham perusahaan makanan dan minuman di Bursa Efek Indonesia periode 2008-2011.

$\mathrm{H}_{\mathrm{A} 3}$ Terdapat pengaruh signifikan secara parsial return on asset terhadap return saham perusahaan makanan dan minuman di Bursa Efek Indonesia periode 2008-2011.

$\mathrm{H}_{04}$ Tidak terdapat pengaruh signifikan secara parsial tingkat bunga SBI terhadap return saham perusahaan makanan dan minuman di Bursa Efek Indonesia periode 2008-2011.

$\mathrm{H}_{\mathrm{A} 4}$ Terdapat pengaruh signifikan secara parsial tingkat bunga SBI terhadap return saham perusahaan makanan dan minuman di Bursa Efek Indonesia periode 2008-2011.

$\mathrm{H}_{05}$ Tidak terdapat pengaruh signifikan secara parsial pertumbuhan ekonomi terhadap return saham perusahaan makanan dan minuman di Bursa Efek Indonesia periode 2008-2011. 
$\mathrm{H}_{\text {A5 }}$ Terdapat pengaruh signifikan secara parsial pertumbuhan ekonomi terhadap return saham perusahaan makanan dan minuman di Bursa Efek Indonesia periode 2008-2011.

$\mathrm{H}_{06}$ Tidak terdapat pengaruh signifikan secara simultan current ratio, debt to equity ratio, return on asset, suku bunga SBI, dan pertumbuhan ekonomi terhadap return saham perusahaan makanan dan minuman di Bursa Efek Indonesia periode 2008-2011.

$\mathrm{H}_{\mathrm{A} 6}$ Terdapat pengaruh signifikan secara simultan current ratio, debt to equity ratio, return on asset, suku bunga SBI, dan pertumbuhan ekonomi terhadap return saham perusahaan makanan dan minuman di Bursa Efek Indonesia periode 2008-2011.

\section{METODOLOGI PENELITIAN}

\section{Obyek Penelitian, Metode Pengumpulan Data, Populasi dan Sampel Penelitian}

Penelitian ini melihat pengaruh faktor-faktor internal dan faktor eksternal terhadap return saham perusahaan makanan dan minuman di Bursa Efek Indonesia dari tahun 2008-2011 sehingga objek penelitiannya adalah perusahaan makanan dan minuman yang terdaftar di BEI periode 2008 - 2011. Penelitian ini merupakan penelitian deskriptif analisis yang dilakukan untuk memperlihatkan dan menguraikan keadaan objek penelitian.

Jenis data yang diperlukan adalah data sekunder antara lain berupa laporan keuangan tahunan perusahaan dan laporan kegiatan perdagangan saham yang didalamnya meliputi variabel likuiditas (current ratio / CR), rasio leverage (debt equity ratio / DER), rasio profitabilitas industri (return on assets / ROA) yang merupakan faktor internal perusahaan, serta faktor eksternal yang dicerminkan melalui dan faktor ekonomi makro (tingkat suku bunga SBI dan pertumbuhan ekonomi) terhadap return saham.

Populasi penelitian ini adalah seluruh perusahaan makanan dan minuman yang listed di Bursa Efek Indonesia dalam periode penelitian antara tahun 2008 sampai dengan 2011. Pengambilan sampel dilakukan dengan teknik purposive sampling yaitu menunjuk langsung suatu populasi berdasarkan karakteristik atau ciri yang dimiliki sampel, dengan tujuan agar diperoleh sampel yang representatif sesuai dengan kriteria yang ditentukan, yaitu perusahaan makanan dan minuman yang tidak pernah keluar bursa (delisting) dari 1 Januari 2008-31 Desember 2011, berturut-turut mengeluarkan laporan keuangan yang sudah diaudit dan dapat diakses selama periode pengamatan dan memiliki informasi tentang harga saham (Adjusted closing price) saat laporan keuangan periode tertentu diterbitkan. Berdasarkan kriteria di atas, diperoleh sampel 16 perusahaan yang memenuhi syarat pemilihan sampel.

\section{Definisi Operasional dan Pengukuran Variabel}

Variabel-variabel yang digunakan dalam penelitian ini terdiri dari variabel terikat dan variabel bebas. Return Saham merupakan variabel terikat $(Y)$, sedangkan yang menjadi variabel bebas $(\mathrm{X})$ terdiri atas $\mathrm{X}_{1}$ adalah Current ratio, $\mathrm{X}_{2}$ adalah Debt To Equity Ratio, $\mathrm{X}_{3}$ adalah Return On Asset, $\mathrm{X}_{4}$ adalah pertumbuhan ekonomi dan $\mathrm{X}_{5}$ adalah suku bunga SBI. Definisi operasional atas variabel-variabel pada penelitian ini perlu dilakukan untuk memudahkan pembahasan lebih lanjut serta untuk menguji hipotesis. Definisi operasional variabel-variabel bebas dan terikat yang digunakan dalam penelitian adalah: 


\section{Variabel Terikat (Dependen)}

Variabel dependen merupakan variabel yang dipengaruhi oleh variabel bebas. Variabel dependen dalam penelitian ini adalah return saham. Data harga saham dalam penelitian ini adalah Adjusted close price pada akhir tahun periode pengamatan. Adapun formulasi return saham adalah:

$$
\text { Return Saham }=\frac{(\text { Adj Close price } t)-(\text { Adj Close price } t-1)}{(\text { Adj Close price } t-1)}
$$

\section{Variabel Bebas (Independen)}

Variabel independen adalah variabel yang menjelaskan atau mempengaruhi variabel lain. Variabel independen dalam penelitian ini adalah :

1. Current Ratio (CR)

Current ratio merupakan salah satu ukuran likuiditas yang bertujuan untuk mengukur kemampuan perusahaan untuk melunasi kewajiban jangka pendeknya dengan aktiva lancar yang dimilikinya. Rumus current ratio (Keown, 2006):

2. Debt To Equity Ratio (DER)

$$
\text { Current Ratio }=\frac{\text { Current Asset }}{\text { Current Liabilities }}
$$

Merupakan rasio hutang yang menggambarkan kemampuan perusahaan memenuhi kewajibannya dan ditunjukkan oleh berapa bagian modal sendiri yang digunakan untuk menbayar hutang-hutang perusahaan. Debt to equity ratio dapat dihitung dengan rumus:

$$
\text { Debt To Equity Ratio }=\frac{\text { Total Debt }}{\text { Total Equity }}
$$

3. Return On Asset (ROA)

Return On Asset merupakan rasio profitabilitas yang digunakan untuk mengukur efektifitas perusahaan di dalam menghasilkan keuntungan dengan memanfaatkan aktiva yang dimilikinya. Return On Asset dapat dihitung dengan rumus (Keown, 2006):

$$
\text { Return On Asset }=\frac{\text { Net Income After Tax }}{\text { Total Asset }}
$$

4. Pertumbuhan ekonomi

5. Suku Bunga SBI

$$
\text { Pertumbuhan ekonomi }_{t}=\frac{G D P \text { riil }_{t}-G D P \text { riil }_{t-1}}{G D P \text { riil }_{t-1}}
$$

Data penelitian ini merupakan tingkat suku bunga SBI dengan deret waktu bulanan yang diubah menjadi rata-rata tingkat suku bunga SBI sebagai penjumlahan suku bunga SBI bulan Januari sampai dengan Desember kemudian dibagi 12 bulan untuk mendapatkan rata-rata suku bunga SBI per tahun. Data berasal dari statistik ekonomi dan keuangan Indonesia dari Laporan Tahunan Bank Indonesia. 


\section{METODE ANALISIS DATA}

\section{Teknik Pengolahan Data dan Estimasi Model Regresi Data Panel}

Penelitian ini menggunakan metode pengolahan regresi data panel dengan cara menggabungkan data time series dan cross section. Biasanya kesulitan yang dialami dalam metode ini terletak pada spesifikasi modelnya, karena ada tiga kemungkinan residual yang muncul yaitu residual time series, cross section maupun gabungan keduanya. Ada tiga pendekatan yang digunakan untuk mengestimasi model regresi dengan data panel yaitu Common Effect, Fixed Effect dan Random Effect. Metode Common Effect (Pooled Least Square) merupakan pendekatan yang paling sederhana dalam mengestimasi data panel karena tidak memperhatikan dimensi waktu dan individual, serta mengasumsikan perilaku data antar perusahaan sama dalam berbagai kurun waktu. Adapun teknik model Fixed Effect mengestimasi data panel dengan menggunakan variabel dummy untuk menangkap adanya perbedaan intersep antara perusahaan namun intersepnya sama antar waktu. Fixed Effect membawa konsekuensi berkurangnya derajat kebebasan yang pada akhirnya mengurangi efisiensi paramater yang bisa diatasi dengan menggunakan variabel gangguan (error terms) dikenal sebagai metode random effects. Teknik ini mengestimasi data panel dimana variabel gangguan mungkin saling berhubungan antar waktu dan antar individu (Widarjono, 2007).

Sesuai dengan jenis data dan alat pengolahan data yang digunakan, maka harus dilakukan langkah-langkah sebagai berikut (Widarjono, 2007):

1. Melakukan estimasi dengan fixed effect

2. Melakukan uji Chow-(Pool vs Fixed Effect) dengan hipotesis:

$\mathrm{H}_{\mathrm{o}}$ : Menggunakan model pool (common)

$\mathrm{H}_{1}$ : Menggunakan model fixed effect

Uji statistik F digunakan untuk memilih antara metode OLS (common) tanpa variabel dummy. Hal ini dilakukan untuk mengambil keputusan apakah sebaiknya menambah variabel dummy untuk mengetahui bahwa intersep berbeda antar perusahaan dengan metode fixed effect. Jika Ho diterima, maka selesai sampai di Uji Chow saja.

3. Estimasi dengan Random Effect

4. Melakukan uji Hausman (Random vs Fixed effect) dengan hipotesis:

$\mathrm{H}_{\mathrm{o}}$ : Menggunakan model random effect

$\mathrm{H}_{1}$ : Menggunakan model fixed effect

Hausman mengembangkan suatu uji statistik untuk memilih penggunaan model Fixed Effect atau Random Effect. Uji Hausman ini didasarkan pada ide bahwa Least Square Dummy Variable (LSDV) di dalam metode Fixed Effect dan Generalized Least Square (GLS) adalah efisien sedangkan metode OLS tidak efisien, di lain pihak alternatifnya metode OLS efisien dan GLS tidak efisien. Oleh karena itu, uji hipotesis nulnya adalah hasil estimasi keduanya tidak berbeda sehingga uji Hausman bisa dilakukan berdasarkan perbedaan estimasi tersebut. Jika Ho diterima, maka selesai sampai di Uji Hausman saja.

\section{Uji Asumsi Klasik}

Uji asumsi klasik bertujuan untuk mengetahui apakah model regresi yang diperoleh dapat menghasilkan estimator linear yang baik. Apabila dalam suatu model telah memenuhi asumsi 
klasik, maka dapat dikatakan model tersebut sebagai model yang ideal atau menghasilkan estimator linier tidak bias yang terbaik (Best Linear Unbiased Estimator / BLUE) (Widarjono, 2007). Dalam penelitian ini dilakukan uji normalitas yang bertujuan untuk mengetahui distribusi data dalam variabel yang digunakan apakah data terdistribusi normal, melalui uji Jargue-Bera test atau J-B test. Jika nilai probablitas yang diperoleh lebih besar dari $\alpha=5 \%$, maka $\mathrm{H}_{0}$ diterima, artinya data berdistribusi normal. Kemudian dilakukan uji multikolinearitas yang berarti adanya hubungan linear yang sempurna atau pasti, diantara beberapa atau semua variabel yang menjelaskan model regresi (Gujarati, 2003). Untuk mengetahui ada atau tidaknya multikolinearitas dapat dilakukan dengan correlation matrix. Apabila koefisien korelasinya kurang dari 0,85 (rule of tumbs 0,85 ) bisa dikatakan tidak terjadi multikolinearitas. Sebaliknya apabila koefisien korelasi melebihi 0,85 bisa dikatakan terjadi multikolinearitas (Widarjono, 2007). Dilanjutkan dengan uji heteroskedastisitas untuk mengetahui adanya ketidaksamaan varian dari residual untuk semua pengamatan pada model regresi. Untuk mengetahui ada atau tidaknya heteroskedastisitas, dapat digunakan uji White dengan melihat probabilitas Chi Squares. Jika nilai probabilitas Chi Squares pada nilai $\mathrm{Obs}^{*} \mathrm{R}$-Square lebih besar dari $\alpha=5 \%$ maka $\mathrm{H}_{\circ}$ diterima, artinya tidak ada heteroskedastisitas. Kemudian dilakukan uji autokorelasi untuk mengetahui ada tidaknya penyimpangan asumsi klasik autokorelasi, yaitu korelasi yang terjadi antara residual pada satu pengamatan dengan pengamatan lain pada model regresi. Dalam mendeteksi ada tidaknya gejala autokorelasi digunakan metode Langrangian Multiplier (LM Test) BreuschGodlfrey.

\section{Analisis Regresi Linier Berganda}

Analisis regresi linier berganda adalah hubungan secara linier antara dua atau lebih variabel independen dengan variabel dependen. Model yang digunakan dalam penelitian ini adalah: $\hat{\mathbf{Y}}_{\mathrm{i}, \mathrm{t}}=\mathbf{a}+\mathbf{b}_{1} \mathbf{X}_{1 \mathrm{i}, \mathrm{t}}+\mathbf{b}_{2} \mathbf{X}_{2 \mathrm{i}, \mathrm{t}}+\mathbf{b}_{3} \mathbf{X}_{3 \mathrm{i}, \mathrm{t}}+\mathbf{b}_{4} \mathbf{X}_{4 \mathrm{i}, \mathrm{t}}+\mathbf{b}_{5} \mathbf{X}_{5 \mathrm{i}, \mathrm{t}}+\boldsymbol{\varepsilon}$

Dimana :

\begin{tabular}{|c|c|}
\hline$\hat{\mathbf{Y}}_{\mathrm{i}, \mathrm{t}}$ & $=$ Return Saham \\
\hline $\mathbf{a}$ & $=$ Konstanta \\
\hline $\mathbf{X}_{1 \mathrm{i}, \mathrm{t}}$ & $=$ Current Ratio \\
\hline $\mathbf{X}_{2 \mathrm{i}, \mathrm{t}}$ & $=$ Debt To Equity Ratio \\
\hline $\mathbf{X}_{3 \mathrm{i}, \mathrm{t}}$ & $=$ Return On Asset \\
\hline $\mathbf{X}_{4 i, t}$ & = Rata-rata Suku Bunga SBI per Tahun \\
\hline $\mathbf{X}_{5 \mathrm{i}, \mathrm{t}}$ & $=$ pertumbuhan ekonomi \\
\hline $\begin{array}{l}\mathbf{b}_{1}, \mathbf{b}_{2}, \mathbf{b}_{3}, \mathbf{b}_{4}, \mathbf{b}_{5} \\
\varepsilon\end{array}$ & $\begin{array}{l}=\text { Koefisien regresi untuk } \mathrm{X}_{1}, \mathrm{X}_{2}, \mathrm{X}_{3}, \mathrm{X}_{4} \text { dan } \mathrm{X}_{5} \\
=\text { Error }\end{array}$ \\
\hline
\end{tabular}

\section{Teknik Pengujian Hipotesis}

\section{Uji t (Parsial) dan Uji F (Simultan)}

Uji t digunakan untuk mengetahui apakah variabel independen $\left(\mathrm{X}_{1}, \mathrm{X}_{2}, \mathrm{X}_{3}, \mathrm{X}_{4}, \mathrm{X}_{5}\right)$ secara individu berpengaruh secara signifikan terhadap variabel dependen ( $\mathrm{Y}$ ) dengan asumsi nilai variabel yang lain adalah konstan. Uji $F$ digunakan untuk mengetahui apakah variabel independen $\left(\mathrm{X}_{1}, \mathrm{X}_{2}, \mathrm{X}_{3}, \mathrm{X}_{4}, \mathrm{X}_{5}\right)$ secara bersama-sama berpengaruh secara signifikan terhadap variabel dependen $(\mathrm{Y})$. 


\section{Uji Koefisien Determinasi $\left(\mathbf{R}^{2}\right)$}

Koefisien determinasi $\left(R^{2}\right)$ mengukur kebaikan sesuai (goodness of fit) dari persamaan regresi yaitu seberapa besar proporsi variasi variabel dependen dijelaskan oleh semua variabel independen (Gujarati, 2003). Nilai koefisien regresi terletak diantara 0 dan 1 . Nilai $R^{2}=1$, berarti variasi variabel independen yang digunakan dalam model menjelaskan $100 \%$ variasi variabel dependen, jika $R^{2}=0$ berarti tidak ada sedikitpun presentasi pengaruh variabel independen terhadap variabel dependen. Berhubung penelitian ini menggunakan lebih dari dua variabel independen, maka digunakan alternatif lain yaitu nilai adjusted $\mathrm{r}^{2}$ karena tidak sensitif terhadap penambahan jumlah variabel independen.

\section{HASIL DAN PEMBAHASAN}

\section{Gambaran Umum Objek Penelitian}

Objek penelitian ini adalah perusahaan yang masuk dalam kategori makanan dan minuman yang listing di BEl selama periode Januari 2008 - Desember 2011. Adapun nama-nama perusahaan tersebut adalah.

Tabel. 1. Nama-Nama Perusahaan pada Industri Makanan dan Minuman

\begin{tabular}{|l|l|l|}
\hline No & Kode Perusahaan & Nama Perusahaan \\
\hline 1 & ADES & Akasha Wira Internasional, Tbk \\
\hline 2 & AISA & Tiga Pilar Sejahtera Food, Tbk \\
\hline 3 & CEKA & Cahaya Kalbar, Tbk \\
\hline 4 & DAVO & Davoman Abadi, Tbk \\
\hline 5 & DLTA & Delta Djakarta, Tbk \\
\hline 6 & FAST & Fast Food Indonesia, Tbk \\
\hline 7 & INDF & Indofood Sukses Makmur, Tbk \\
\hline 8 & MLBI & Multi Bintang Indonesia, Tbk \\
\hline 9 & MYOR & Mayora Indah, Tbk \\
\hline 10 & PSDN & Prasidha Aneka Niaga, Tbk \\
\hline 11 & SIPD & Sierad Produce, Tbk \\
\hline 12 & SKLT & Sekar Laut, Tbk \\
\hline 13 & SMAR & Smart, Tbk \\
\hline 14 & STTP & Siantar Top, Tbk \\
\hline 15 & TBLA & Tunas Baru Lampung, Tbk \\
\hline 16 & ULTJ & Ultra Jaya Milk Industry \& Trad \\
\hline
\end{tabular}

Sumber: BEI

Dari 16 perusahaan yang mewakili industri makanan dan minuman tersebut, akan dianalisa return saham masing-masing perusahaan apakah dipengaruhi oleh faktor internal maupun eksternal. Faktor internal meliputi current ratio, debt to equity ratio, dan return on asset, sedangkan faktor ekternal adalah tingkat bunga sbi dan pertumbuhan ekonomi. Berikut adalah statistik deskriptif untuk penelitian ini. 
Tabel. 2. Statistika Deskriptif

\begin{tabular}{|l|c|c|c|c|c|c|}
\hline & RS? & CR? & DER? & ROA? & SBI? & PERTU? \\
\hline Mean & 0.387893 & 1.710527 & 1.172411 & 0.075181 & 0.078646 & 0.058058 \\
\hline Median & 0.378363 & 1.715000 & 1.048404 & 0.066380 & 0.086300 & 0.061000 \\
\hline Maximum & 2.455108 & 2.790000 & 3.110000 & 0.236100 & 0.091800 & 0.063000 \\
\hline Minimum & -0.785965 & 0.513882 & 0.199466 & -0.029600 & 0.062900 & 0.046000 \\
\hline Std. Dev. & 0.725492 & 0.530781 & 0.739220 & 0.056571 & 0.011731 & 0.006403 \\
\hline Skewness & 0.460059 & -0.140660 & 0.617113 & 0.828879 & -0.233678 & -1.301477 \\
\hline Kurtosis & 2.966305 & 2.646259 & 2.413951 & 3.104628 & 1.410820 & 2.872888 \\
\hline & & & & & & \\
\hline Jarque-Bera & 1.836800 & 0.442593 & 4.044661 & 5.978073 & 5.945149 & 4.714980 \\
\hline Probability & 0.399157 & 0.801479 & 0.132347 & 0.050336 & 0.051171 & 0.090638 \\
\hline & & & & & & \\
\hline Sum & 20.17046 & 88.94742 & 60.96536 & 3.909389 & 4.089600 & 3.019000 \\
\hline Sum Sq. Dev. & 26.84329 & 14.36813 & 27.86879 & 0.163216 & 0.007018 & 0.002091 \\
\hline & & & & & & \\
\hline
\end{tabular}

sumber: olahan penulis

Berdasarkan tabel 2 yang menunjukkan perhitungan statistic, dapat diketahui bahwa return saham industri makanan dan minuman rata-rata sebesar 0.3878 dengan nilai tertinggi sebesar 2.455 dan terendah sebesar -0.7859 . Current ratio selama periode $2008-2011$ untuk industri makanan dan minuman memiliki rata-rata sebesar 1.710 dengan nilai tertinggi sebesar 2.79 dan terendah sebesar 0.5138. Debt to equity ratio ataupun return on asset selama periode 2008 2011 rata-rata masing-masing sebesar 1.172 dan 0.075 . Untuk faktor ekternal perusahaan, SBI rata-rata sebesar 0.0786 dan pertumbuhan ekonomi rata-rata sebesar 0.058 . Selain itu semua variabel penelitian yaitu RS, CR, DER, ROA, SBI, maupun PERTU memiliki data yang terdistribusi normal, yang dapat dilihat dari nilai prob Jarque Berra di atas nilai signifikansi $5 \%$, yang berarti residual data terdistribusi normal.

\section{ANALISA HASIL}

\section{Penentuan metode panel data}

Sebelum dilakukan analisa hasil regresi, harus terlebih dahulu ditentukan metode data panel yang digunakan. Terdapat tiga jenis metode data panel, yaitu common effect, fixed effect, dan random effect. Penentuan penggunaan common atau fixed effect menggunakan Uji Chow, yang hasilnya dapat dilihat pada tabel 3.

\section{Tabel. 3. Uji Chow}

Redundant Fixed Effects Tests

Pool: POOL1

Test cross-section fixed effects

\begin{tabular}{lrrr}
\hline \hline Effects Test & Statistic & d.f. & Prob. \\
\hline \hline Cross-section F & 0.650920 & $(14,32)$ & 0.8020 \\
Cross-section Chi-square & 13.030442 & 14 & 0.5241 \\
\hline \hline
\end{tabular}

Sumber: Olahan penulis 
Dapat dilihat bahwa prob $\mathrm{F}$ sebesar 0.8020 yang lebih besar dari tingkat signifikansi $(\alpha)=$ $5 \%$, sehingga dapat disimpulkan bahwa metode panel data yang digunakan adalah common effect. Jika sudah memilih metode panel data common effect maka tidak perlu menguji penggunaan random effect dengan menggunakan Haussman Test.

\section{Uji asumsi klasik}

\section{Uji Multikolinearitas}

Pengujian multikolinearitas menggunakan correlation matrix untuk melihat seberapa kuat hubungan antar variabel independen dapat dilihat pada tabel berikut:

Tabel. 4. Correlation Matrix

\begin{tabular}{|c|c|c|c|c|c|}
\hline & CR & DER & ROA & SBI & PERTU \\
\hline CR & 1 & 0.400369778 & -0.17350784 & -0.08976394 & -0.14945667 \\
\hline DER & 0.400369778 & 1 & -0.006223049 & 0.022591037 & -0.14928032 \\
\hline ROA & -0.173507844 & -0.006223049 & 1 & -0.178979276 & -0.18867393 \\
\hline SBI & -0.089763941 & 0.022591037 & -0.178979276 & 1 & 0.292355231 \\
\hline PERTU & -0.149456671 & -0.149280320 & -0.188673938 & 0.292355231 & 1 \\
\hline
\end{tabular}

Sumber: Olahan Penulis

Berdasarkan tabel di atas, dapat dilihat bahwa semua variabel independen yaitu CR, DER, ROA, SBI, dan PERTU memiliki korelasi yang kecil yang berarti tidak ada masalah multikolinearitas.

\section{Pengujian Heterokedastisitas}

Metode pengujian yang digunakan untuk menguji heteroskedastisitas dalam penelitian ini adalah uji white heterocedasticity. Tabel 5 menampilkan hasil dari proses uji heterokedastisitas. Nilai signifikansi pada tabel output sebesar 0.9336 lebih besar dari tingkat signifikansi 0.05 menunjukkan bahwa tidak terjadi heteroskedastisitas dalam model ini.

Tabel .5. Uji Heterokedastisitas

Heteroskedasticity Test: White

\begin{tabular}{lclc}
\hline \hline F-statistic & 0.520255 & Prob. F(18,45) & 0.9336 \\
Obs*R-squared & 11.02434 & Prob. Chi-Square(18) & 0.8933 \\
Scaled explained & & & \\
SS & 20.30751 & Prob. Chi-Square(18) & 0.3158 \\
Sumber: Olahan Penulis & &
\end{tabular}

\section{Pengujian Otokorelasi}

Pengujian otokorelasi menggunakan pengujian Breusch-Godlfrey. Hasil pengujian dapat dilihat pada tabel 6 berikut yang menunjukkan bahwa nilai prob F sebesar 0.53 lebih besar dari tingkat signifikansi $(\alpha)=5 \%$, yang berarti tidak ada autokorelasi. 
Tabel. 6. Pengujian Otokorelasi

Breusch-Godfrey Serial Correlation LM Test:

\begin{tabular}{lrll}
\hline \hline F-statistic & 0.642150 & Prob. F(2,56) & 0.5300 \\
Obs ${ }^{*}$ R-squared & 1.434864 & Prob. Chi-Square(2) & 0.4880 \\
Sumber: Olahan Penulis & &
\end{tabular}

\section{Analisa regresi}

Berdasarkan hasil pengujian regresi menggunakan common effect, maka dihasilkan persamaan regresi berganda sebagai berikut:

$$
\begin{gathered}
R S=0.708+0.731 C R+0.326 D E R+4.723 R O A-21.227 S B I-11.02 P E R T U \\
(3.705) \\
(2.265)
\end{gathered}
$$

Dari persamaan tersebut dapat ditarik kesimpulan sebagai berikut:

1. Koefisien dari CR (current ratio) sebesar 0.731, yang berarti jika CR naik 1 satuan maka return saham perusahaan di industri makanan dan minuman pada tahun 2008 - 2011 sebesar 0.731 satuan dengan asumsi faktor lain konstan.

2. Koefisien DER (debt to equity ratio) sebesar 0.326, yang berarti jika DER naik 1 satuan makan return saham perusahaan di industri makanan dan minuman pada tahun 2008-2011 sebesar 0.326 satuan dengan asumsi faktor lain konstan

3. Koefisien dari ROA (return on asset) sebesar 4.723, yang berarti jika ROA naik 1 satuan maka return saham perusahaan di industri makanan dan minuman pada tahun $2008-2011$ sebesar 4.723 satuan dengan asumsi faktor lain konstan.

4. Koefisien dari SBI (Sertifikat Bank Indonesia) sebesar -21.227, yang berarti jika SBI naik 1 satuan maka return saham perusahaan di industri makanan dan minuman pada tahun 2008 - 2011 akan turun sebesar 21.227 satuan dengan asumsi faktor lain konstan.

5. Koefisien dari PERTU (pertumbuhan ekonomi) sebesar -11.02 , yang berarti jika PERTU naik 1 satuan maka return saham perusahaan di industri makanan dan minuman pada tahun 2008 - 2011 akan turun sebesar 11.02 satuan dengan asumsi faktor lain konstan.

Dari hasil persamaan tersebut, selanjutnya akan diuji tingkat signifikansi baik parsial maupun simultan berdasarkan perumusan masalah dalam penelitian ini sebagai berikut:

1. Pengujian hipotesa 1

Hasil persamaan regresi menunjukkan nilai sig sebesar 0.0006 yang berarti lebih kecil dari tingkat signifikansi $(\alpha)=5 \%$, hal ini menunjukkan secara parsial terdapat pengaruh signifikan current ratio terhadap return saham. Semakin tinggi nilai current ratio perusahaan maka nilai return saham perusahaan akan meningkat.

2. Pengujian hipotesa 2

Nilai sig pengujian hipotesa 2 sebesar 0.0285 lebih kecil dari tingkat signifikansi $5 \%$, yang berarti secara parsial terdapat pengaruh signifikan debt to equity ratio terhadap return saham.

3. Pengujian hipotesa 3

Hasil pengujian menunjukkan nilai sig sebesar 0.0031 yang lebih kecil dari tingkat signifikansi, yang berarti terdapat pengaruh signifikan return on asset terhadap return saham perusahaan makaan dan minuman periode 2008-2011. 
4. Pengujian hipotesa 4

Terdapat pengaruh signifikan SBI terhadap return saham dengan nilai sig sebesar 0.0047 yang lebih kecil dari tingkat signifikansi. Semakin tinggi tingkat bunga SBI, semakin rendah nilai return saham.

5. Pengujian hipotesa 5

Secara parsial tidak terdapat pengaruh signifikan pertumbuhan ekonomi terhadap return saham industri makanan dan minuman karena nilai sig sebesar 0.4093 lebih besar dari tingkat signifikansi.

6. Pengujian hipotesa 6

Secara simultan terdapat pengaruh signifikan dari CR, DER, ROA, SBI, dan PERTU terhadap return saham, yang ditunjukkan dengan nilai sig $\mathrm{F}$ sebesar 0.000. Hasil koefisien determinasi sebesar 0.3703 menunjukkan CR, DER, ROA, SBI, dan PERTU mempengaruhi return saham industri makanan dan minuman pada periode $2008-2011$ sebesar 37,03\%, sisanya $62,97 \%$ dipengaruhi faktor lain di luar model regresi.

\section{SIMPULAN DAN SARAN}

Berdasarkan hasil penelitian dapat disimpulkan bahwa:

1. Secara parsial, terdapat pengaruh signifikan current ratio, debt to equity ratio, return on asset, dan tingkat bunga SBI terhadap return saham pada industri makanan dan minuman periode 2008 - 2011.

2. Secara parsial, tidak terdapat pengaruh signifikan antara pertumbuhan ekonomi terhadap return saham pada industri makanan dan minuman periode 2008 - 2011.

3. Secara simultan, terdapat pengaruh signifikan current ratio, debt to equity ratio, return on asset, tingkat bunga SBI, dan pertumbuhan ekonomi terhadap return saham terhadap pada industri makanan dan minuman periode $2008-2011$.

Adapun saran yang dapat diberikan adalah:

1. Manajemen perusahaan agar memperhatikan kondisi kesehatan keuangan perusahaan, karena hasil penelitian ini menunjukkan semua faktor internal perusahaan memiliki hubungan yang signifikan.

2. Pemerintah supaya menjaga kestabilan tingkat suku bunga khususnya tingkat bunga SBI, karena mempunyai pengaruh terhadap return saham perusahaan.

3. Dapat dilakukan penelitian lebih lanjut pada sektor industri yang berbeda tidak hanya pada sektor industri makanan dan minuman saja, sehingga dapat dilihat apakah hasil penelitian dapat digeneralisir.

\section{DAFTAR PUSTAKA}

Andyono, 2009, "Analisis Pengaruh Variabel Fundamental Perusahaan dan Kondisi Makroekonomi Terhadap Tingkat Imbal Hasil Saham Perusahaan Industri Pertambangan Di BEl Periode 2004-2008', Skripsi, Universitas Indonesia

Ang, Robert, 1997, Buku Pintar pasar Modal Indonesia, Media Soft Indonesia

Gujarati, 2007, Essential of Econometrics, Mc Graw-Hill

Husnan, Suad, 2003, Dasar-dasar Teori Portofolio dan Analisa Sekuritas, UPP AMP YKPN 
Jones, Charles. 2007, Investment: Analysis and Management, J Wiley

Keown, Arthur J, 2006, Financial Management: Principles and Aplications, Prentice Hall Mankiw, N. G. 2006. Principles of Economics. $3^{\text {rd }}$ Edition. Ohio: Thomson South-Western.

Sekaran, Uma. 2006. Metodologi Penelitian Untuk Bisnis. Jakarta: Salemba Empat.

Subalno, 2009, "Analisis Pengaruh Faktor Fundamental dan Kondisi Ekonomi Terhadap Return

Saham (Study Kasus Pada Perusahaan Otomotif dan Komponen Yang Listed di Bursa Efek Indonesia Periode 2003-2007)", skripsi, Universitas Diponegoro

Subramanyam dan Wild, 2008, Financial Statement Analysis, Mc Graw-Hill

Usman, Marzuki., Singgih Riphat dan Syahrir Ika, 1997, Pengetahuan Dasar Pasar Modal, Institut Bankir Indonesia.

Utami, Mudji dan Mudjilah Rahayu, 2009, "Peran Profitabilitas, Suku Bunga, Inflasi dan Nilai Tukar Dalam Mempengaruhi Pasar Modal Indonesia Selama Krisis Ekonomi", skripsi, Universitas Surabaya

Widarjono, 2007, Ekonometrika: Pengantar dan Aplikasinya, Ekonisia. 